\title{
A new microcosm to investigate oxygen dynamics at the sea ice water interface
}

\author{
Thomas Mock $^{1, *}$, Marcel Kruse ${ }^{2}$, Gerhard S. Dieckmann ${ }^{1}$ \\ ${ }^{1}$ Alfred Wegener Institute for Polar and Marine Research, Am Handelshafen 12, 27570 Bremerhaven, Germany \\ ${ }^{2}$ Denkmanufaktur GmbH, Vor der Reihe 1, 26197 Großenkneten, Germany
}

\begin{abstract}
A laboratory sea ice microcosm was developed to enable the cultivation of the ice diatom Fragilariopsis cylindrus in the skeletal layer and bottom $10 \mathrm{~cm}$ of sea ice. Growth of diatoms was ensured by continuous flow of new medium beneath the ice. Light was provided from above by a metal halide lamp to simulate a typical natural daylight irradiance spectrum. Oxygen microoptodes were deployed in the microcosm to measure micro-profiles through the ice water interface and between the ice lamellae of the skeletal layer. Net oxygen production at the ice water interface, at an irradiance of $40 \mu \mathrm{mol}$ photons $\mathrm{m}^{-2} \mathrm{~s}^{-1}$ and $-1.9^{\circ} \mathrm{C}$, ranged between 0.0064 and $0.0225 \mathrm{nmol} \mathrm{O}_{2}$ $\mathrm{cm}^{-2} \mathrm{~s}^{-1}$. Algal biomass increased from $0.03 \mu \mathrm{g}$ chlorophyll a ( $\mathrm{chl} \mathrm{a}$ ) $\mathrm{l}^{-1}$ in the column interior to $42 \mu \mathrm{g}$ $\mathrm{chl} \mathrm{a} \mathrm{l}^{-1}$ within $5 \mathrm{~mm}$ of the ice water interface. Oxygen micro-profiles revealed diffusive boundary layers (DBLs) which varied between ca. 460 and $1000 \mu \mathrm{m}$. DBLs were detected between ice lamellae, the periphery of the ice water interface and extending from the water below the ice through the ice water interface into the spaces between ice lamellae. An additional small-scale horizontal variability of DBLs was also reflected in the net photosynthetic activity. The small-scale patchiness of algae and the differences in DBL thickness were caused by physico-chemical processes (e.g. turbulence, water flow velocity), which in turn were influenced by ice lamellar structure at the ice water interface. These factors were the grounds for the observed variability in net-photosynthesis.
\end{abstract}

KEY WORDS: Fragilariopsis cylindrus · Methods · Microcosm • Micro-optodes • Oxygen · Photosynthesis $\cdot$ Sea ice

\section{INTRODUCTION}

The sea ice habitat is still a relatively under-explored research area. Although we have a reasonable understanding of the physics and ecology of sea ice-covered seas (Brierley \& Thomas 2002, Thomas \& Dieckmann 2002), biogeochemical processes taking place within the sea ice matrix are still largely unknown. This is due to limited access to sea ice throughout the year and the difficulties with sampling and in situ measurements (Smith \& Hermann 1991, Mock \& Gradinger 1999, McMinn et al. 2000, Kühl et al. 2001, Rysgaard et al. 2001). In the past decade, sea ice research has begun to benefit from the development of new technologies that enable the investigation of the sea ice interior

*Email: tmock@awi-bremerhaven.de
(Mock \& Gradinger 1999, Eicken et al. 2000, Junge et al. 2001) and the elucidation of small-scale oxygen distribution within brine channels during sea ice formation (Mock et al. 2002) and at the ice water interface (McMinn et al. 2000, Kühl et al. 2001, Rysgaard et al. 2001, Glud et al. 2002, Trenerry et al. 2002).

For the first time oxygen micro-optodes have enabled us to measure oxygen directly within sea ice brine channels or pockets without disturbing the ice matrix or the brine chemistry (Mock et al. 2002). However, this was only possible by freezing the sensors into growing ice. In consolidated ice, processes are best measured by adapting non-invasive methodologies such as NMR (nuclear magnetic resonance) (Eicken et al. 2000), cryo-microscopes (Junge et al. 2001) or PAM (pulse amplitude modulated fluorescence measurements) while sensors and microelectrodes are ideal for studying the ice water interface (McMinn et al. 2000, 
Kühl et al. 2001, Rysgaard et al. 2001, Glud et al. 2002, Trenerry et al. 2002). Microelectrodes have been used to measure the diffusive boundary layer (DBL) of oxygen at the ice water interface in order to quantify net photosynthesis of algae (McMinn et al. 2000), which grow there. Sufficient nutrient supply, relatively constant temperatures and large spaces between the ice lamellae support the rich growth of sea ice algae within these few $\mathrm{mm}$ of sea ice called the skeletal layer (Horner et al. 1992). The most successful organisms living under these conditions are diatoms, which contribute a large proportion of the total polar primary productivity (e.g. Warwick 1988, Gleitz et al. 1998, Lizotte 2001).

The skeletal layer of sea ice consists of ice lamellae with pore spaces up to $1200 \mu \mathrm{m}$ wide (Williams et al. 1992, Wettlaufer et al. 1997a, Krembs et al. 2000). The spacial complexity of this layer results from small-scale differences in pore space, which is related to lamellar growth and brine movement (Wettlaufer et al. 1997b). The skeletal layer and lamellae are a very dynamic interface due to fluctuating ice and water temperatures (Worster \& Wettlaufer 1997). The critical factor affecting ice growth and the ablation of the skeletal layer is the flux of energy through the ice; hence, the steepness of the temperature gradient. Traditional investigations into ice cores or the use of divers to deploy chambers in situ have not yet been able to explain the complex processes at the ice water interface. There is an evident need for laboratory experiments and defined conditions to understand the consequences of variability of the ice water interface (Worster \& Wettlaufer 1997) and the photosynthetic dynamics of ice-algae under simulated in situ conditions.

The aim of this study was to cultivate ice algae at the ice water interface using a microcosm under simulated in situ conditions, and to investigate the variability of DBLs on small spatial scales to infer the net photosynthesis of ice algae using oxygen microsensors (optodes). This approach was a further step towards unravelling the effect of small-scale variability on primary productivity at the sea ice water interface.

\section{MATERIALS AND METHODS}

Microcosm experiment. Artificial sea ice was formed in a $25 \mathrm{l}$ acrylic-glass cylinder (height $=80 \mathrm{~cm}$; radius $=10 \mathrm{~cm}$ ) fixed in a supporting frame and placed in a freezer room (Fig. 1). The microcosm was filled with $0.2 \mu \mathrm{m}$ filtered Antarctic seawater and inoculated with f/2 nutrients (Guillard \& Ryther 1962). The cylinder was insulated with polystyrene plates to ensure freezing from the water surface downwards and not from the sides. After a decrease in the air temperature to $-20^{\circ} \mathrm{C}$, the ice thickness reached $40 \mathrm{~cm}$ within $2 \mathrm{~d}$. The seawater below the ice was then exchanged with nutrient-enriched seawater (f/2) of 34 salinity, using a flow-through system at the base of the cylinder. The circulation system ensured a homogenous salinity and nutrient regime below the ice. Once these conditions had been established, $50 \mathrm{ml}$ of a dense axenic Fragilariopsis cylindrus culture $\left(5 \times 10^{5}\right.$ cells ml $\left.{ }^{-1}\right)$ was added through a septum in the bottom of the cylinder. The polystyrene insulation was removed and subsequent cooling continued at $-10^{\circ} \mathrm{C}$ air temperature. Further freezing was controlled by transparent heating foils (Minco Products) surrounding the bottom $7 \mathrm{~cm}$ of the cylinder. Freezing was continued and regulated to allow incorporation of algae into the growing skeletal layer. The continuous flow-through system ensured a stable salinity of ca. 36 and constant nutrient supply. Seawater below the ice (ca. 2.5 l) was exchanged completely every $3 \mathrm{~d}$. Continuous illumination was provided from above by a $250 \mathrm{~W}$ metal halide lamp (Siemens). A heat cut-off filter (KG1 Schott) between the lamp and the cylinder prevented melting of the ice surface. A stable skeletal layer of approximately $1 \mathrm{~cm}$ thickness harbouring growing algae was established after ca. $6 \mathrm{mo}$, following which the micro-optode experiments were started.

Pumps, fresh medium and a bottle for the overflow were maintained at $\mathrm{ca} .+10^{\circ} \mathrm{C}$ air temperature in a room adjacent to the freezer. Flexible tubes (inlet and outlet) linking this room and the microcosm were insulated to avoid freezing of the flow-through system.

Temperature and light measurements. Ice and water temperatures were monitored at irregular intervals prior to the establishment of stable sea ice conditions using an array of thermistors on the inside of the cylinder wall. Temperature recordings and visual observation of the skeletal layer helped to maintain stable conditions therein. The thermistor array comprised 8 Siemens K17 thermistors with a vertical spacing of $9 \mathrm{~cm}$, installed $3 \mathrm{~cm}$ above the bottom of the cylinder. The thermistors extended horizontally $1.5 \mathrm{~cm}$ into the ice column.

Scalar irradiance $(\mathrm{PAR}=$ photosynthetically active radiation [400 to $700 \mathrm{~nm}$ ] in $\mu \mathrm{mol}$ photons $\mathrm{m}^{-2} \mathrm{~s}^{-1}$ ) was measured on the top of sea ice with a LI-COR 1000 radiometer and a $4 \pi$ sensor during each experiment. In order to determine PAR at the ice water interface, fluxes were calculated from the surface scalar irradiance using Beer's law:

$$
E_{\mathrm{i}}=E_{\mathrm{t}} \times \mathrm{e}^{\left[-a-k_{\mathrm{i}} \times d_{z}+k_{\mathrm{chl}} \times \operatorname{chl}(z)\right]}
$$

where $E_{\mathrm{t}}=$ PAR on the sea ice surface; $E_{\mathrm{i}}=$ PAR at ice water interface; $a=$ albedo ( 0.7 for frozen white ice) (Perovich 1996); $k_{\mathrm{i}}=$ diffusive attenuation coefficient 


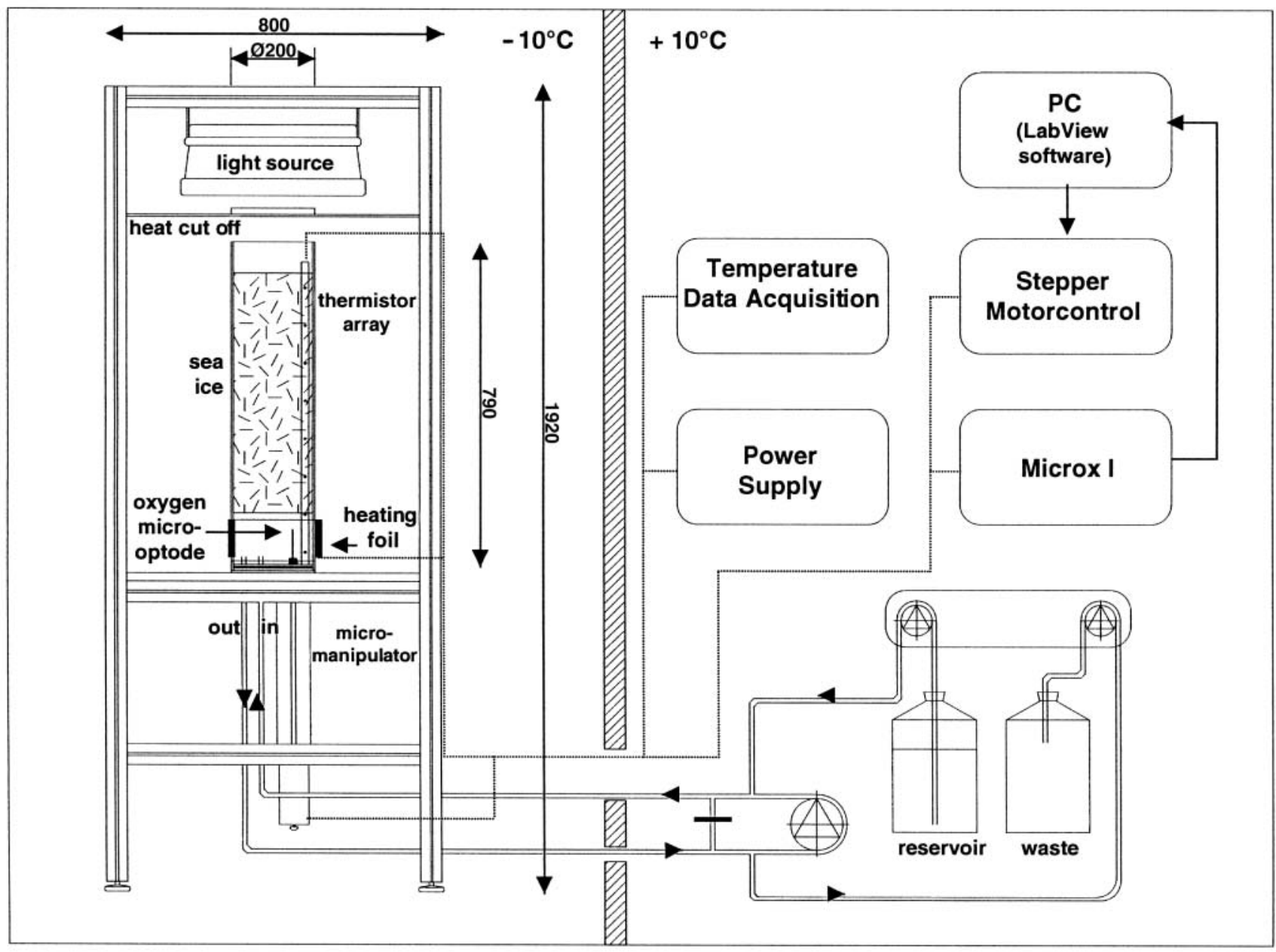

Fig. 1. Scheme of microcosm experiment. Scale given in $\mathrm{mm}$

for ice $\left(1.5 \mathrm{~m}^{-1}\right.$ ) (Maykut 1985); $d_{z}=$ ice layer thickness $(\mathrm{m}) ; k_{\mathrm{chl}}=$ mean spectral attenuation coefficient for chlorophyll a (chl a) $\left(0.035 \mathrm{~m}^{2} \mathrm{mg}^{-1}\right)$ (Smith et al. 1988); $\operatorname{chl}(z)=\operatorname{chl}$ a concentration in ice $\left(\mathrm{mg} \mathrm{m}^{-2}\right)$.

Oxygen measurements. Micro-optodes of Type A, with a measuring range from 0 to $500 \%$ air saturation (PreSens, Precision Sensing), were used to measure the oxygen dynamics within the skeletal layer, under ice water and the diffusive boundary layers. The sensor fibre has a diameter of $140 \mu \mathrm{m}$ and is tapered to a tip of ca. $40 \mu \mathrm{m}$. This makes them ideal for inserting into the spaces (up to a diameter of $3000 \mu \mathrm{m}$ ) of the skeletal layer (ca. lowermost $10 \mathrm{~mm}$ of sea ice). To introduce the sensor into the ice, the optical fibre was passed through a standard syringe $(1 \mathrm{ml})$ with a $30 \mathrm{~cm}$ needle. Micro-optodes were calibrated at $-2^{\circ} \mathrm{C}$ in aerated seawater with a salinity of 36 and $100 \%$ air saturation and a solution of $0.5 \% \mathrm{NaSO}_{3}(0 \%$ oxygen). This calibration was conducted before and at the end of each measurement. The maximum sensor drift observed was a decrease of $7.3 \%$ air saturation (primary Microx meter signal), after $24 \mathrm{~h}$ sensor deployment in sea ice. A micro temperature sensor was pushed through a silicon septum into the lowermost $\mathrm{mm}$ of the skeletal layer to determine whether a temperature gradient, which would effect the optode signal, existed between the water below the ice and the lowermost $\mathrm{mm}$ of the skeletal layer. No gradient was measured. Since salinity and temperature are correlated we also ruled out a salinity gradient (Cox \& Weeks 1983). Oxygen sensors were operated from below the cylinder using a motorised micromanipulator (NL4 Isel), to guide the sensors through the silicon septum visually to a position between the ice lamellae. The ice underside was defined as the zone where the micro-optode tip disappeared between ice lamellae. Visual guiding was possible because the ice water interface was relatively flat.

The micromanipulator was connected to a computer and a Microx I sensor control box (PreSens). Oxygen 
measurements were based on the luminescence lifetime of the immobilised luminophore as the oxygendependent parameter (for further details see: www. presens.de). Signals of the micromanipulator (sensor depth) and the micro-optodes (oxygen as \% air saturation) were processed and visualised using custom made Labview software (National Instruments), which also controlled the propulsion of the sensor into the ice.

The sensor was moved through the spaces between the ice lamellae in 6 to $100 \mu \mathrm{m}$ steps with more than 4 measurements of oxygen per step and a temporal resolution of $1 \mathrm{~s}$. A $24 \mathrm{~h}$ time series measurement of oxygen concentration was also conducted. Calculations of oxygen concentrations were made according to the Microx manual. The oxygen concentration as \% air saturation was calculated according to Eq. (2):

$$
\left[\mathrm{O}_{2}\right]=\frac{1-\frac{\tan \Phi}{\tan \Phi_{0}}}{\mathrm{~K}_{\mathrm{SV}} \times\left\{\frac{\tan \Phi}{\tan \Phi}-0.11\right\}}
$$

where $\Phi_{0}=$ phase angle of oxygen-free water; $\Phi=$ measured phase angle $\mathrm{K}_{\mathrm{SV}}=$ Stern-Volmer constant; $\left[\mathrm{O}_{2}\right]=$ oxygen content as \% air saturation.

The conversion of $\%$ air saturation into $\mu \mathrm{mol} \mathrm{O}_{2} \mathrm{l}^{-1}$ is obtained with Eq. (3):

$$
\begin{aligned}
{\left[\mathrm{O}_{2}\right]\left(\mu \mathrm{mol} l^{-1}\right)=} & {\left[\frac{p_{\mathrm{atm}}-p_{\mathrm{w}}(T)}{p_{\mathrm{N}}} \times \frac{\% \text { air saturation }}{100} \times 0.2095\right.} \\
& \left.\times \alpha\left(T ; C l^{-}\right) \times 1000 \times \frac{M\left(\mathrm{O}_{2}\right)}{V_{\mathrm{M}}}\right] \times 31.25
\end{aligned}
$$

where $p_{\text {atm }}=$ actual atmospheric pressure $; p_{\mathrm{N}}=$ standard pressure (1013 mbar); $0.2095=$ volume content of oxygen in air; $p_{\mathrm{w}}(T)=$ vapor pressure of water at temperature $T(\mathrm{~K}) ; M\left(\mathrm{O}_{2}\right)=$ molecular mass of oxygen $\left(31.25 \mathrm{~g} \mathrm{~mol}^{-1}\right) ; V_{\mathrm{M}}=$ molar volume $\left(22.414 \mathrm{l} \mathrm{mol}^{-1}\right)$; $\alpha\left(T_{;} \mathrm{Cl}^{-}\right)=$Bunsen absorption coefficient at water temperature $T\left(271^{\circ} \mathrm{K}\right)$ and chlorinity (20), which is assumed to be the same within the lowermost few $\mathrm{mm}$ of sea ice.

Photosynthesis. Net photosynthesis was calculated by using diffusive oxygen fluxes $(J)$ based on the 1dimensional version of Fick's first law of diffusion (Revsbech \& Jørgensen 1986):

$$
J=D_{\mathrm{O}} \frac{\mathrm{d} C(z)}{\mathrm{d} z}
$$

where $D_{\mathrm{O}}$ is the molecular diffusion coefficient (at $-1.9^{\circ} \mathrm{C}=1.11 \times 10^{-5} \mathrm{~cm}^{2} \mathrm{~s}^{-1}$; Broecker \& Peng 1974) and $\mathrm{d} C / \mathrm{d} z$ is the concentration gradient.

Micro-optode experiments were conducted in a stable skeletal layer for a period of $5 \mathrm{~d}$. This was an important prerequisite for the growth of diatoms. Without stable conditions the skeletal layer would either disappear by melting or advance by continuing lam- ellar growth. Both processes cause strong biomass fluctuation and changes in mass transfer of salt and gas (Glud et al. 2002). An outflow of dense brine was only observed during the initial stages of ice growth and not during oxygen measurements within the stable skeletal layer. The optode sensor tips were placed into the spaces of the skeletal layer up to a maximum distance of $2 \mathrm{~mm}$ without damage to the fragile tips or the ice lamellae. Whenever ice lamellae appeared to flake off, the measurements were abandoned. Sixteen micro-profiles were successfully completed, of which 3 examples are shown (see Fig. 4a,b,c). Five successful time series measurements were carried out, 1 of which is shown in Fig. 3.

Salinity, nutrient and pigment measurements. After the micro-optode experiments were completed, the sea ice column was removed from the cylinder. The bottom $10 \mathrm{~cm}$ of the ice column was cut into 5 and $10 \mathrm{~mm}$ horizontal sections using a stainless steel saw and melted at $4^{\circ} \mathrm{C}$ in the dark. Salinity of the melted ice sections was determined with a WTW (Wissenschaftlich Technische Werkstätten) salinometer and the brine volume fraction of ice was calculated according to Cox \& Weeks (1983). Nutrient concentrations were determined according to standard seawater procedures in Grasshoff et al. (1983). For the determination of algal pigment concentrations (chl a and phaeopigments), thawed core sections were filtered onto Whatman GF/F filters extracted in $90 \%$ acetone and analysed fluorometically with a Turner Designs Model 10-AU digital fluorometer according to Arar \& Collins (1992).

\section{RESULTS}

Sea ice formation began from the seawater surface after cooling below $-2^{\circ} \mathrm{C}$. A sea ice column of $60 \mathrm{~cm}$ had developed down to the heating foils after $8 \mathrm{~d}$. The sea ice column was characterised by higher temperatures at the top and bottom with a minimum in the centre (Fig. 2). The air temperature increase from -20 to $-10^{\circ} \mathrm{C}$ caused a general increase in sea ice temperatures and a reduction of the steep gradient in the bottom of the sea ice. A stable skeletal layer had developed ca. 1 mo later without any measurable variance in sea ice thickness. The micro-optode experiments were conducted 18 d later.

Dissolved oxygen concentrations between ice lamellae fluctuated over time as indicated by results obtained during $24 \mathrm{~h}$ period and under continuous light (Fig. 3). Strong fluctuations were recorded within the first $11 \mathrm{~h}$, followed by a stable period for $5 \mathrm{~h}$ and a steep rise and continued increase in oxygen.

Oxygen microprofiles across the ice water interface and within the ice were highly variable. Three differ- 


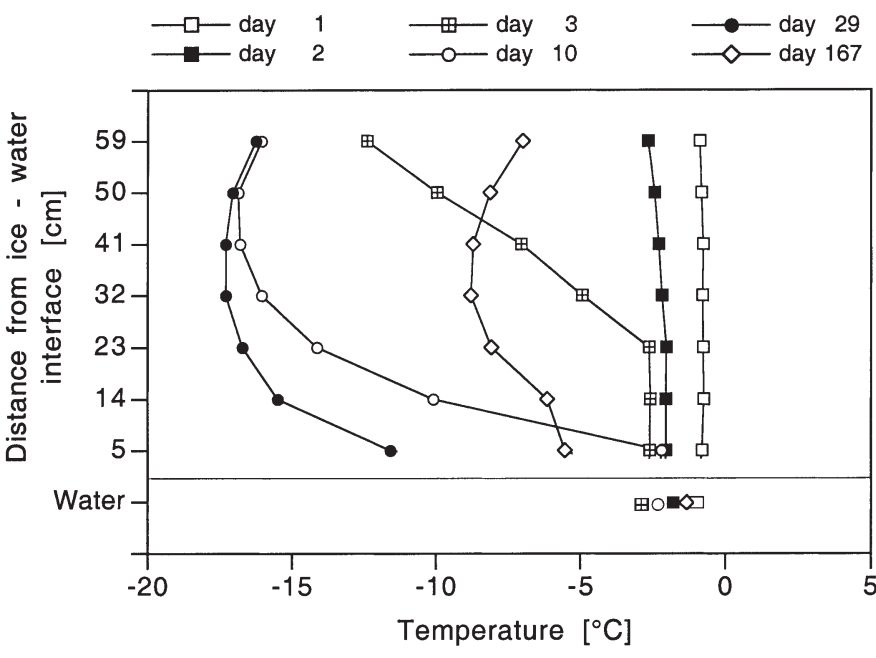

Fig. 2. Thermistor measurements in sea ice and seawater from the beginning of surface sea ice development at Day 1 to fully stabile ice conditions at Day 167

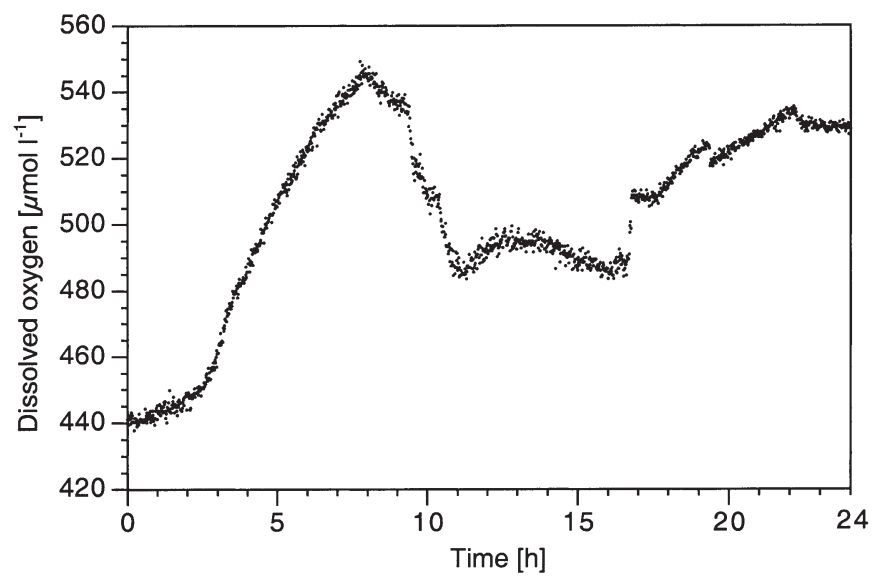

Fig. 3. Continuous measurements of dissolved oxygen concentrations within 1 brine channel of the skeletal layer measured over $24 \mathrm{~h}$ and continuous illumination

ent scenarios were observed: (1) a linear increase in oxygen concentration, which represented the diffusive boundary layers beginning with increasing concentrations in the water below the ice (Fig. 4a), (2) an increase beginning at the ice water interface (Fig. 4b) or (3) an increase beginning only between the ice lamellae (Fig. 4c). Only diffusive boundary layers within ice lamellae were used to determine net oxygen flux using Eq. (4). Net oxygen export ranged between 0.0064 and $0.0225 \mathrm{nmol} \mathrm{O}_{2} \mathrm{~cm}^{-2} \mathrm{~s}^{-1}$ depending on the steepness of the dissolved oxygen gradient. The strongest gradient was measured within the ice, $1.5 \mathrm{~mm}$ from the ice water interface (Fig. 4c).

Chl $a$ in the sea ice column was detectable to a distance of $100 \mathrm{~mm}$ from ice water interface $(0.03 \mu \mathrm{g}$
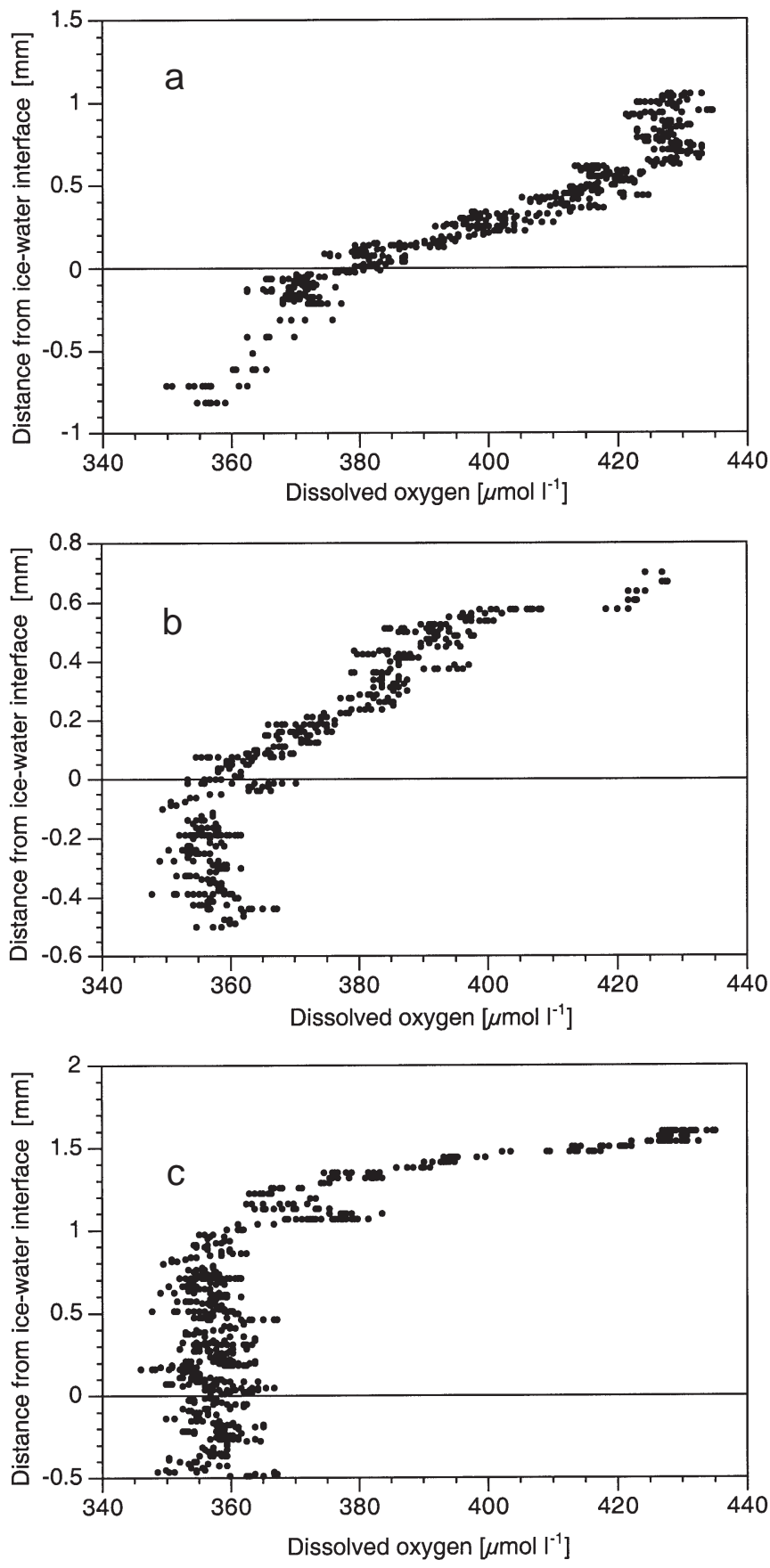

Fig. 4. Micro-profiles of dissolved oxygen measured at the sea ice water interface: (a) linear increase in oxygen concentrations, which represented the diffusive boundary layers beginning with increasing concentrations in the water below the ice; (b) increase beginning at the ice water interface; (c) increase beginning only between the ice lamellae

chl a $\mathrm{l}^{-1}$ ) (Fig. 5) increasing steadily to a maximum of

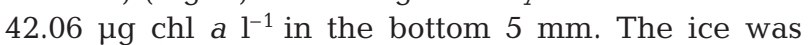
characterised by a bulk salinity gradient (Fig. 6) with a minimum at $40 \mathrm{~cm}$ below the surface and a maximum 


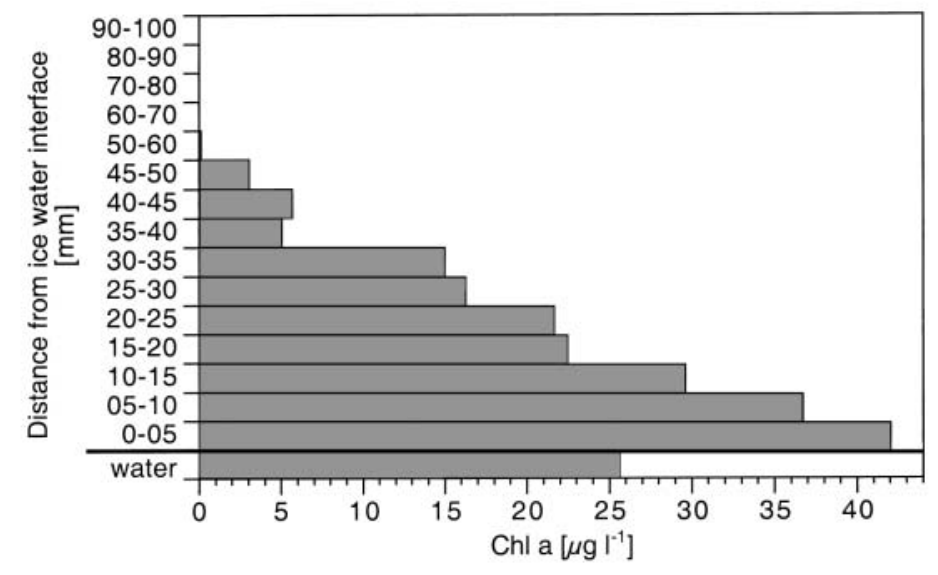

Fig. 5. Chl a distribution in the bottom $10 \mathrm{~cm}$, where Fragilariopsis cylindrus was cultured at the ice water interface, which coincided with the biomass peak of Fragilariopsis cylindrus. The maximum brine volume of $50 \%$ also occurred at the ice water interface (Fig. 6). Nutrient concentrations were exceptionally high as expected for artificially enriched seawater (Fig. 7). The vertical distribution of nutrients through the bottom $100 \mathrm{~mm}$ of sea ice followed the bulk salinity profile with lowest nutrient concentrations in the interior and increasing concentrations towards the ice water interface.

Scalar irradiance at the top of the ice was $561 \mu \mathrm{mol}$ photons $\mathrm{m}^{-2} \mathrm{~s}^{-1}$ during the experiments. Calculated scalar irradiance experienced by the algae at the ice water interface was $40 \mu \mathrm{mol}$ photons $\mathrm{m}^{-2} \mathrm{~s}^{-1}$.

\section{DISCUSSION}

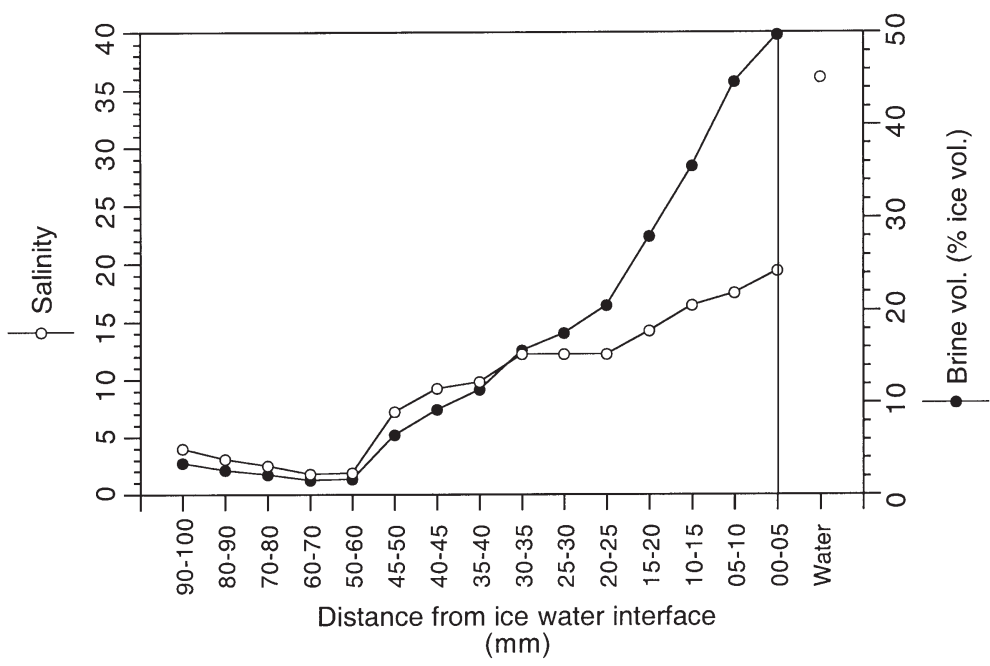

Fig. 6. Vertical profile of salinity in melted ice sections and relative brine volume as \% of ice volume over the bottom $10 \mathrm{~cm}$
The skeletal layer is characterised as a 3-dimensional network of ice lamellae, interspersed with layers of brine (e.g. Weissenberger et al. 1991), and differs structurally from sediment or stone surfaces. This was shown by our fluctuating oxygen measurements. Strongly fluctuating oxygen concentration in a brine channel, observed during a $24 \mathrm{~h}$ period of continuous illumination, is probably related to several factors. Percolation of brine occurred within the ice, which could cause a local decrease of oxygen concentration (Glud et al. 2002), although brine drainage was not observed. Brine from the interior of colder ice has a higher salinity and consequently lower oxygen concentration (Sherwood et al. 1991, Mock et al. 2002). Photosynthetic activity is reduced as salinity increases (Bates \& Cota 1986, Mock \&

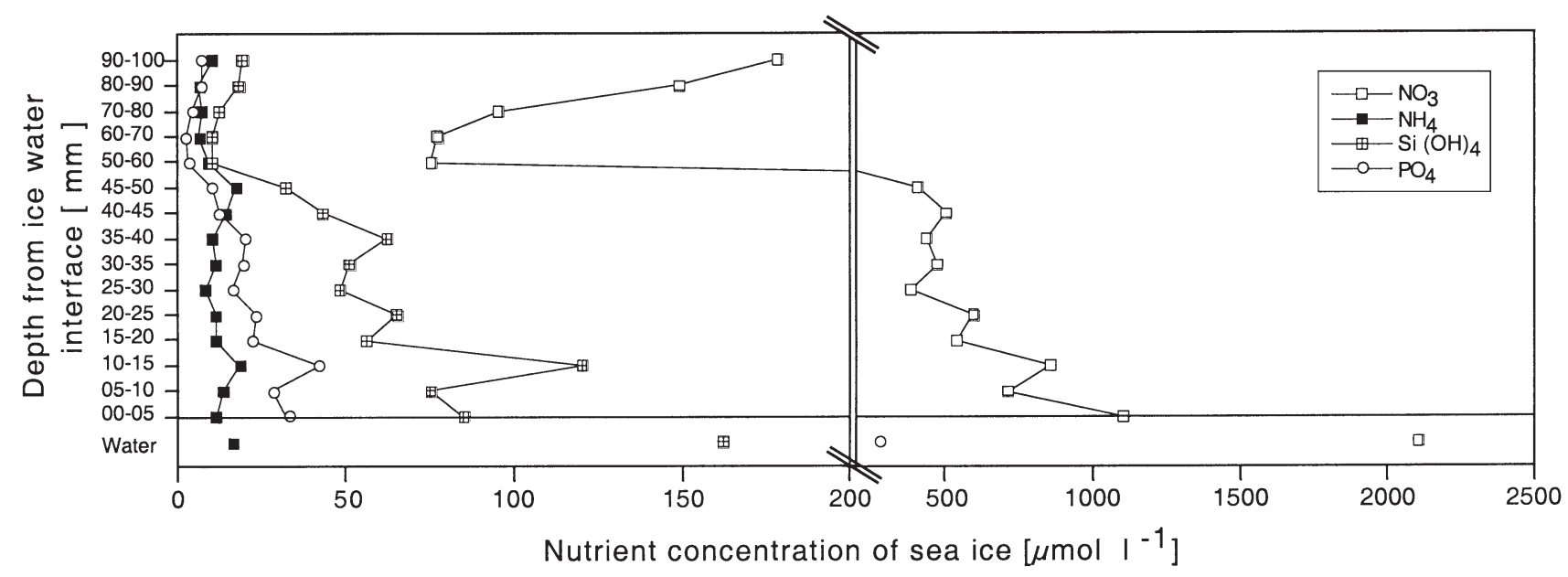

Fig. 7. Vertical profiles of nutrients in melted ice sections over the bottom $10 \mathrm{~cm}$ 
Fig. 8. ice water interface with large ice lamellae in the skeletal layer (bottom $10 \mathrm{~mm}$ of sea ice)

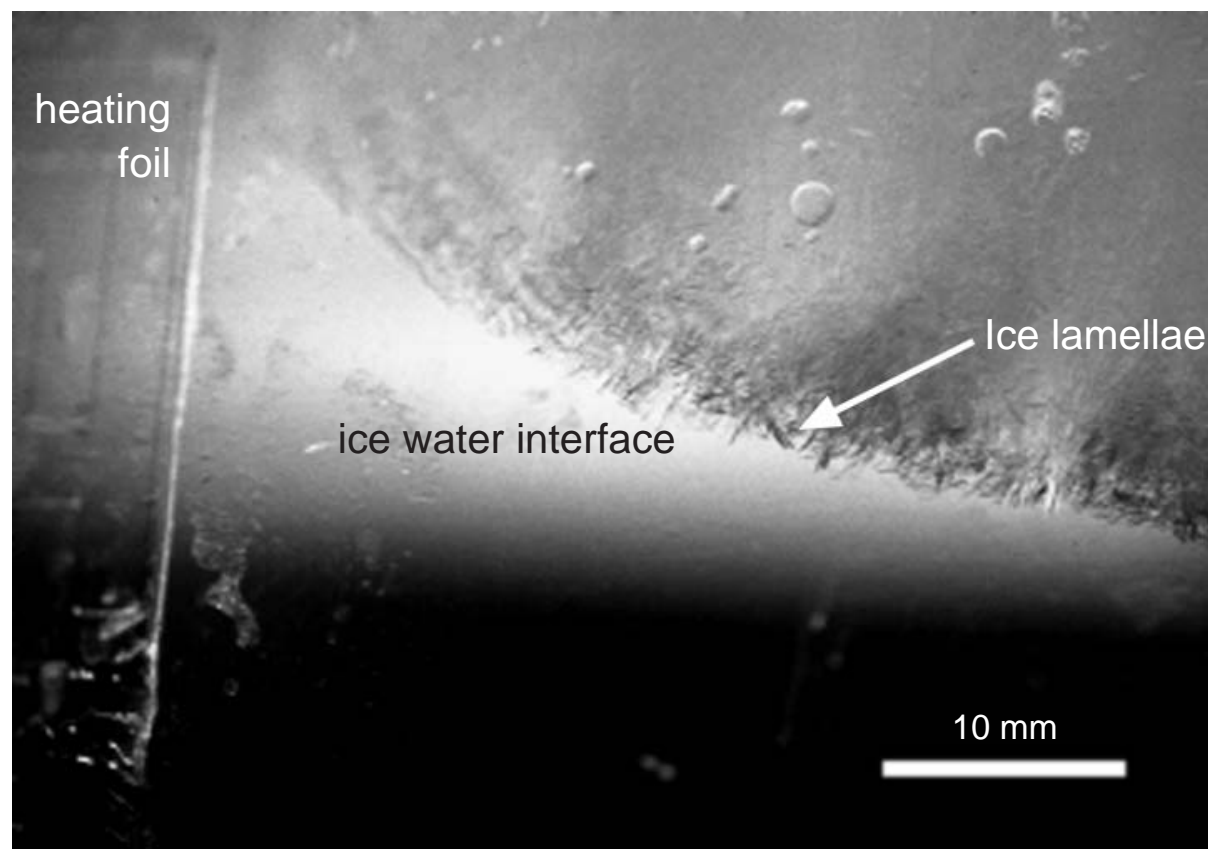

Gradinger 1999). The general trend, however, was an increase in oxygen concentration over time due to photosynthetic activity of Fragilariopsis cylindrus.

Oxygen micro-profiles revealed varying thicknesses of the DBL within a distance of a few $\mathrm{cm}$. This implies a complex surface topography and thus an intricate DBL topography (Jørgensen \& DesMaris 1990). We assume that DBLs develop at the base of each ice lamella, which also appears to be the locality of the algae. Thus a 1-dimensional geometry for 1-dimensional diffusion calculations still exists, albeit on a small scale. The 1-dimensional geometry changes to a radial geometry with increasing distance from the ice water interface, where vein-like brine channels dominate. The DBL thickness ranged from ca. $460 \mu \mathrm{m}$ to $>1000 \mu \mathrm{m}$ across the ice water interface (Fig. 4). Differences in DBL thickness of the ejected seawater are affected by flow velocities and turbulence which are dependent on surface roughness (Jørgensen \& Revsbech 1985). The roughness of the ice water interface which existed over different metric scales is assumed to be the main reason for strong variability of the boundary layer thickness. Our results demonstrate that the DBLs at the ice water interface and below the ice are in fact influenced by different sizes of ice lamellae (Fig. 8). It is well known from sediment studies that grains or pellets above 0.2 to $0.4 \mathrm{~mm}$ in size cause measurable deviations of the DBL thickness (Jørgensen \& Revsbech 1985). The ice lamellae at the ice water interface were longer than $0.4 \mathrm{~mm}$ (Fig. 8). Gas bubbles, which formed during ice formation as a result of increasing salinities (salting-out effect) could also have contributed to the complex behaviour of oxygen at the ice water interface (Tsurikov 1979). However, this physical effect is assumed to be small within the stable skeletal layer.

The complex DBL topography can affect the transport coefficient and thus would invalidate the use of a 1dimensional diffusion approach to estimate solute fluxes (M. Kühl pers. comm.) This is obviously even more the case under natural conditions. For instance, a significant mass transfer of salt and gases occurs, particularly during sea ice growth or melt or any other physical force, which causes advection of brine at the sea ice water interface. Such processes are probably negligible in our microcosm. Nonetheless, our calculated fluxes are comparable to oxygen fluxes measured under natural conditions (Table 1) (McMinn \& Ashworth 1998, McMinn 2000, Buffan-Dubau 2001, Trenerrry et al. 2001). This could possibly be related to similar stable conditions whenever these natural oxygen fluxes were measured.

Strong differences in net photosynthesis determined in studies of natural sea ice populations were related to differences in assimilation numbers. The reported assimilation numbers for sea ice studies ranged from 0.0002 (Trenerry et al. 2001) to $2.0100 \mathrm{mg} \mathrm{C} \mathrm{mg}^{-1} \mathrm{chl} \mathrm{a}$ $\mathrm{h}^{-1}$ (McMinn 2000), which was attributed to large differences in algal biomass between studies and large spatial heterogeneity of the sea ice algae. In future, we will have to measure chl $a$ in the spatially confined areas in which we have determined the oxygen distribution (Kühl \& Fenchel 2000). As the chl a measurements were imprecise, we did not attempt to calculate assimilation numbers for the algae. 
Table 1. Net photosynthesis ( $\mathrm{nmol} \mathrm{O}_{2} \mathrm{~cm}^{-2} \mathrm{~s}^{-1}$ ) measured by microsensors in different microbial mats. Irradiance is given as photosynthetic active radiation (PAR) in $\mu \mathrm{mol}$ photons $\mathrm{m}^{-2} \mathrm{~s}^{-1}$ and temperature is given in ${ }^{\circ} \mathrm{C}$

\begin{tabular}{|lcccll|}
\hline $\begin{array}{l}\text { Type of } \\
\text { measurement }\end{array}$ & $\begin{array}{c}\text { Net } \\
\text { photosynthesis }\end{array}$ & Irradiance & Temp. & \multicolumn{1}{c|}{ Area } & Source \\
\hline Artificial & $0.015-0.282$ & $16-200$ & $20-22$ & Skødstrup (Denmark) & Kühl et al. (1996) \\
Artificial & $0-0.0042$ & $0.1-33.1$ & -1.0 & Davis (Antarctica) & McMinn \& Ashworth (1998) \\
Natural & 0.2 & 180 & 21 & Wismar Bay (Germany) & Epping et al. (1999) \\
Natural & $0.10-0.38$ & 425 & $25-40$ & Solar Lake (Egypt) & Wieland \& Kühl (2000) \\
Artificial & 0.12 & 413 & 20 & Niva Bay (Denmark) & Kühl \& Fenchel (2000) \\
Natural & $0.0084-0.0440$ & $3-55$ & -1.8 & Cap Evans (Antarctica) & McMinn et al. (2000) \\
Artificial & $0.0083-0.0517$ & 70 & 6 & Lake Fryxell (Antarctica) & Buffan-Dubau et al. (2001) \\
Natural & $0.0001-0.0034$ & $0.2-7$ & -1.9 & Cap Evans (Antarctica) & Trenerry et al. (2001) \\
Artificial & $0.0064-0.0225$ & 40 & -1.9 & Artificial substrate & This study \\
\hline
\end{tabular}

The multi-factorial influence of oxygen distribution debilitates the quantification of photosynthesis or the estimation of overall large-scale productivity from microprofiles. Primary production estimates of natural ice algal communities should therefore, in the foreseeable future, be conducted with radio-labelled tracers under in situ conditions (Mock 2002).

\section{CONCLUSION}

Fine-scale studies of oxygen measurements at the ice water interface, especially within the undisturbed sea ice skeletal layer, are still rare (McMinn et al. 2000, Kühl et al. 2001, Rysgaard et al. 2001, Glud et al. 2002). The described culture chamber used to grow sea ice and microalgae within sea ice over an extended time period (1 yr and longer) enables visible and mechanical access with micro-optodes to an undisturbed ice water interface. This preliminary investigation opens new perspectives in the use of new sensors such as micro PAM (pulse amplitude modulated fluorometer) sensors (Walz), $\mathrm{CO}_{2}$ and $\mathrm{pH}$ sensors (PreSens) in sea ice research. The microcosm also enabled us to study ice algal photosynthesis, simulation of ice melt processes, changes in light intensity/spectrum (UV) and nutrient limitation via the flow-through system. Chemical processes in sea ice can be studied without the influence of biology (Glud et al. 2002). Consequently this microcosm is a tool for future research to bridge gaps in our knowledge of micro-environmental controls at the sea ice water interface.

Acknowledgements. David N. Thomas is thanked for reviewing an earlier version of the manuscript, and making suggestions for its improvement. We are also grateful to Michael Kühl and Andrew McMinn and 1 anonymous reviewer for helpful comments about an earlier version of this article. Special thanks to Erika Allhusen for her excellent technical assistance.

\section{LITERATURE CITED}

Arar EJ, Collins GB (1992) In vitro determination of chlorophyll $a$ and phaeophytin $a$ in marine and freshwater phytoplankton by fluorescence: method 445.0. In: US EPA (ed) Methods for the determination of chemical substances in marine and estuarine environmental samples. US EPA, Cincinnati, $\mathrm{OH}, \mathrm{p} 1-22$

Bates SS, Cota GF (1986) Fluorescence induction and photosynthetic response of Arctic ice algae to sample treatment and salinity. J Phycol 22:421-429

Brierley AS, Thomas DN (2002) The ecology of Southern Ocean sea ice. Adv Mar Biol 43:171-276

Broecker WS, Peng TH (1974) Gas exchange rates between air and sea. Tellus 26:21-35

Buffan-Dubau E, Pringault O, de Wit R (2001) Artificial coldadapted microbial mats cultured from Antarctic lake samples. 1. Formation and structure. Aquat Microb Ecol 26:115-125

Cox GFN, Weeks WF (1983) Equations for determining the gas and brine volumes in sea ice samples. J Glaciol 29: 306-316

Eicken H, Bock C, Wittig R, Miller H, Poertner HO (2000) Magnetic resonance imaging of sea-ice pore fluids: methods and thermal evolution of pore microstructure. Cold Reg Sci Technol 31:207-225

Epping EHG, Khalili A, Thar R (1999) Photosynthesis and the dynamics of oxygen consumption in a microbial mat as calculated from transient oxygen microprofiles. Limnol Oceanogr 44:1936-1948

Gleitz M, Bartsch A, Dieckmann GS, Eicken H (1998) Composition and succession of sea ice diatom assemblages in the eastern and southern Weddell Sea, Antarctica. In: Lizotte MP, Arrigo KR (eds) Antarctic sea ice: biological processes, interactions and variability. Antarc Res Ser (AGU) 73:107-120

Glud RN, Rysgaard S, Kühl M (2002) A laboratory study on $\mathrm{O}_{2}$ dynamics and photosynthesis in ice algal communities: quantification by microsensors, $\mathrm{O}_{2}$ exchange rates, ${ }^{14} \mathrm{C}$ incubations and PAM fluorometer. Aquat Microb Ecol 27: 301-311

Grasshoff K, Erhard M, Kremling K (1983) Methods of sea water analyses, 2nd edn. Verlag Chemie, Weinheim

Guillard RR, Ryther JH (1962) Studies of marine plankton diatoms. I. Cyclotella nana (Husted) and Detonula confervacea (Cleve). Can J Microbiol 8:229-239

Horner R, Ackley SF, Dieckmann GS, Gulliksen B and 6 others (1992) Ecology of sea ice biota. 1. Habitat, terminology, and methodology. Polar Biol 12:417-427 
Jørgensen BB, Des Marais DJ (1990) The diffusive boundary layer of sediments: oxygen microgradients over a microbial mat. Limnol Oceanogr 35:1343-1355

Jørgensen BB, Revsbech NP (1985) Diffusive boundary layers and the oxygen uptake of sediments and detritus. Limnol Oceanogr 30:111-122

Junge K, Krembs C, Deming J, Stierle A, Eicken H (2001) A microscopic approach to investigate bacteria under in situ conditions in sea ice samples. Ann Glaciol 33:304-310

Krembs C, Gradinger R, Spindler M (2000) Implications of brine channel geometry and surface area for the interaction of sympagic organisms in Arctic sea ice. J Exp Mar Bio Ecol 243:55-80

Krembs C, Tuschling K, Juterzenka KV (2002) The topography of the ice water interface - its influence on the colonization of sea ice by algae. Polar Biol 25:106-117

Kühl M, Fenchel T (2000) Bio-optical characteristics and the vertical distribution of photosynthetic pigments and photosynthesis in an artificial cyanobacterial mat. Microb Ecol 40:94-103

Kühl M, Glud RN, Ploug H, Ramsing NB (1996) Microenvironmental control of photosynthesis and photosynthesiscoupled respiration in an epilithic cyanobacterial biofilm. J Phycol 32:799-812

Kühl M, Glud RN, Borum J, Roberts R, Rysgaard S (2001) Photosynthetic performance of surface associated algae below sea ice as measured with a pulse amplitude modulated (PAM) fluorometer and $\mathrm{O}_{2}$ microsensors. Mar Ecol Prog Ser 223:1-14

Lizotte MP (2001) The contributions of sea ice algae to Antarctic marine primary production. Am Zool 41:57-73

Maykut GA (1985) The ice environment. In: Horner R (ed) Sea ice biota. CRC Press, Boca Raton, FL, p 21-82

McMinn A, Ashworth C (1998) The use of oxygen microelectrodes to determine the net production by an Antarctic sea ice algal community. Antarct Sci 10:39-44

McMinn A, Ashworth C, Ryan KG (2000) In situ net primary productivity of an Antarctic fast ice bottom algal community. Aquat Microb Ecol 21:177-185

Mock T (2002) In situ primary production in young Antarctic sea ice. Hydrobiologia 470:127-132

Mock T, Gradinger R (1999) Determination of Arctic ice algal production with a new in situ incubation technique. Mar Ecol Prog Ser 177:15-26

Mock T, Dieckmann GS, Haas C, Krell A, Tison JL, Belem AL, Papadimitriou S, Thomas DN (2002) Micro-optodes in sea ice: a new approach to investigate oxygen dynamics during sea ice formation. Aquat Microb Ecol 29:297-306

Editorial responsibility: Karin Lochte,

Kiel, Germany
Perovich DK (1996) The optical properties of sea ice. Cold Regions Research and Engineering Laboratory Monograph, Office of Naval Research, Arlington, VA, p 1-24

Revsbech NP, Jørgensen BB (1986) Microelectrodes: their use in microbial ecology. In: Marshall KC (ed) Advances in microbial ecology, Vol 9. Plenum Press, New York, p 293-352

Rysgaard S, Kühl M, Glud RN, Hansen JW (2001) Biomass, production and horizontal patchiness of sea ice algae in a high-Arctic fjord (Young Sound, NE-Greenland). Mar Ecol Prog Ser 223:15-26

Sherwood JE, Stagnitti F, Kokkin MJ, Williams WD (1991) Dissolved oxygen concentrations in hypersaline waters. Limnol Oceanogr 36(2):235-250

Smith REH, Herman AW (1991) Productivity of sea ice algae: In situ vs. incubator methods. J Mar Syst 2:97-110

Smith REH, Anning J, Clement P, Cota G (1988) Abundance and production of ice algae in Resolute Passage, Canadian Arctic. Mar Ecol Prog Ser 48:251-263

Trenerry LJ, McMinn A, Ryan KG (2002) In situ oxygen microelectrode measurements of the bottom-ice algal production in McMurdo Sound, Antarctica. Polar Biol 25: $72-80$

Tsurikov VL (1979) The formation and composition of the gas content of sea ice. J Glaciol 22(86):67-81

Warwick VF (1988) Microbial ecosystems of Antarctica. Cambridge University Press, Cambridge

Weissenberger J, Dieckmann GS, Gradinger R, Spindler M (1991) Sea ice: a cast technique to examine and analyze brine pockets and channel structure. Limnol Oceanogr 37: 179-183

Wettlaufer JS, Worster MG, Huppert HE (1997a) The phase evolution of young sea ice. Geophys Res Lett 23: 1251-1254

Wettlaufer JS, Worster MG, Huppert HE (1997b) Natural convection during solidification of an alloy from above with application to the evolution of sea ice. J Fluid Mech 344: 291-316

Wieland A, Kühl M (2000) Short-term temperature effects on oxygen and sulfide cycling in a hypersaline cyanobacterial mat (Solar Lake, Egypt). Mar Ecol Prog Ser 196:87-102

Williams KL, Garrison GR, Mourad PD (1992) Experimental examination of growing and newly submerged sea ice including acoustic probing of the skeletal layer. J Acoust Soc Am 92:2075-2092

Worster MG, Wettlaufer JS (1997) Natural convection, solute trapping, and channel formation during solidification of saltwater. J Phys Chem 101:6132-6136

Submitted: April 22, 2002; Accepted: September 12, 2002

Proofs received from author(s): December 2, 2002 